\title{
Motivational factors affecting informal women entrepreneurs in North-West Province
}

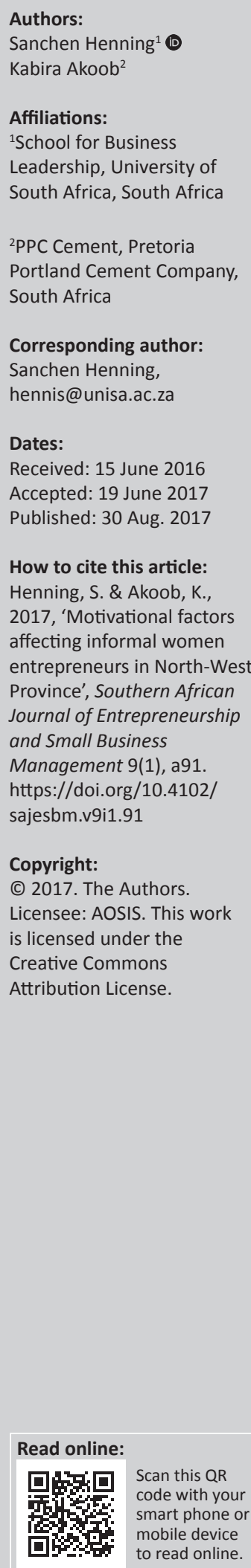

Background: Informal women entrepreneurs in the rural villages of North-West strive to progress from poverty to prosperity. There is a growing appreciation that the conditions that support women's ability to start and grow ventures may be different from those that help men and therefore there is a need to examine the motivational factors affecting women's enterprise development.

Aim: The study aimed to identify the motivational factors of women in the Mahikeng area to start informal enterprises, the barriers they experience and their developmental business needs.

Setting: The study focussed on informal women entrepreneurs in the rural villages of Mahikeng in the North-West province.

Methods: In total, 80 face-to-face questionnaires were completed with women entrepreneurs. A principal component analysis of 15 items of the total questionnaire was performed on the data to determine which items could be reduced and transformed into new components.

Results: 'Destitute conditions', 'Entrepreneurial Spirit' and 'Passion for Product' emerged as the three underlying motivational factors. The component 'Destitute conditions' was ranked as the most important reason for starting an informal business. The need to transcend impoverished conditions (a push factor) and the need for self-determination (a pull factor) were almost equally strong amongst the 80 participants. 'Lack of financial and business skills' was ranked as the biggest obstacle to keeping the business running. Ninety-one per cent of the women entrepreneurs reported that they had never received any training from the government or the private sector.

Conclusions: Access to basic infrastructure, training, funding and business networks will enable self-efficacy behaviour of women entrepreneurs in the Mahikeng district to move beyond poverty. Recommendations included the establishment of a regional database of informal women entrepreneurs, the improvement of basic facilities and infrastructure and access to microloans as well as training by the formal sector.

\author{
Our deepest fear is not that we are inadequate \\ Our deepest fear is that we are powerful beyond measure \\ It is our light, not our darkness \\ That most frightens us. \\ Marianne Williamson (1993:57)
}

\section{Introduction}

And the Little Engine thought of the good little boys and girls on the other side of the mountain who would not have any toys or good food unless she helped. Then she said, 'I think I can. I think I can. I think I can.' In the children's book The Little Engine That Could (Piper 1978), the tiny (female) engine thought about how the little boys and girls on the other side of the mountain would not have their toys and food unless she helped. The story describes a simple but powerful concept characteristic of informal women entrepreneurs in rural settlements in North-West Province. Self-efficacy is a learned human pattern of thinking rather than a genetically endowed personality trait (Snyder \& Lopez 2007). The behaviourist Bandura (1982:122) defined self-efficacy as people's beliefs in their capabilities to produce desired effects by their own actions. The research revealed that the informal women entrepreneurs in the Mahikeng rural district intend to move the food and toys to the other side of the mountain through self-determination but need business education and financial support to grow their businesses out of survival mode into profit maximisation. There is a growing appreciation that the conditions that support women's ability to start and grow ventures may be different from those that help men and therefore there is a need 
to examine the motivational factors affecting women's enterprise development (Bosma 2014).

Entrepreneurial self-efficacy refers to the strengths of an individual's belief that he or she has the capability of performing the roles and tasks of an entrepreneur and represents what the individual thinks he or she can realise with his or her skills (Saadaoui \& Affess 2015). The achievement, motivation and self-assurance of female entrepreneurs in a patriarchal African society are negatively affected by the social structures that oppress them (Hechavarria \& Ingram 2016). In this context, a woman is not expected to make economic decisions such as starting a business and requesting resources and goods to make it work but rather tend to home responsibilities.

The North-West Province where Mahikeng is situated recorded the largest annual decrease in the official unemployment rate amongst the nine provinces in South Africa (Stats SA 2014), from 26.8\% to 25.2\%. Despite this fact, the province has a labour force participation rate of 2.3\% (Stats SA 2014). The majority of households are headed by women as men are mostly migrant labourers on mines. They live with fewer resources, fewer rights and fewer opportunities because of factors such as domestic violence, the lack of education and gender discrimination. There is a significant intersection between being a woman, working in the informal sector and being poor (Sethuraman \& Chames 1998). A higher percentage of people in the informal sector relative to the formal sector are poor. Informal economic activities are unrecorded but are estimated at a value of $28 \%$ of South Africa's total gross domestic product (GDP). That is R160 billion, which makes its value 2.5 times as large as the contribution of the entire agricultural sector, or $70 \%$ of the contribution of the mining sector to GDP (Stats SA 2014).

Despite robust growth in the African economies during the last decade (Ayub 2013) many Africans continue to live in poverty. As long as African economies fail to provide employment for all their citizens, informal businesses will remain an alternative means of survival in Africa (SiqwanaNdulo 2013a). Prahalad (2005) states that the poor market or Bottom of the Pyramid should not merely be seen as producers but also as consumers, implying that there is potentially a large market as well as many opportunities available in the informal business sector. While a few studies on motivational factors of female entrepreneurs in formal businesses exist, there is limited literature on female entrepreneurs in the informal sector in South Africa.

Motivation concerns what moves people to act, think and develop. Self-motivation involves behaviour that could be both intrinsically and extrinsically motivated. Intrinsic motivation refers to engagement in activities because a person wants to. There are no external rewards or punishment involved and it is associated with feeling good and functioning well. Also referred to as a 'pull factor', intrinsic motivation prompts a person to perform an activity because of the positive feelings resulting from it (Wissing et al. 2015).
Intrinsic motivation enhances independent and responsible behaviour as the more fully an individual is apprised of what is occurring internally, the healthier, adaptive and valueconsistent his or her behaviour is likely to be (Brown \& Ryan 2004). In short, an individual decides through internal motivation how to act, think and develop.

In contrast, extrinsic motivation involves a tangible reward or the avoidance of pain or suffering and can be described as 'push factors' in life. Brown and Ryan (2004) explain that from early childhood, there is a dramatic shift in the ratio of intrinsic to extrinsic motivation in the direction of extrinsic activities. External regulation needs to be internalised to mature into self-responsibility in a person. In South Africa, social grants to the poor as an external motivator could foster dependency and undermine responsible, self-regulated behaviour. Having more children may be interpreted as having more money without having to put in any effort.

Motivational orientations (push or pull factors) are described as constructs in self-determination theory (Brown \& Ryan 2004). The authors argued that motivational orientations guide behaviour and have important consequences for psychological well-being. The necessity- and opportunity drivers of entrepreneurial behaviour emerged as an analytical framework against which developing countries started to gauge how the activities that entrepreneurs engage in differ (Williams \& Gurtoo 2012). This binary analytical framework may over-simplify the complex rationales of entrepreneurs and this view was put under the spotlight to give recognition to those entrepreneurs in developing countries who voluntarily engage in entrepreneurial endeavours out of choice and not as a survival strategy.

This article aims to identify the motivational factors that affect women in the Mahikeng district to start informal enterprises.

The informal economy has particular relevance for the creation of employment opportunities and alleviating poverty as part of individual survival strategies of the poor (South African LED Network 2010).

\section{The importance of informal entrepreneurship}

The informal economy forms a key component of strategies to alleviate poverty and to support the creation of sustainable livelihoods. By its very nature, informal economic activity goes unrecorded and is therefore difficult to measure, but some estimates value the informal economy at around $28 \%$ of South Africa's GDP. The majority of municipalities fail in providing local economic development (LED)-friendly and inclusive informal economy policies and by-laws (SiqwanaNdulo 2013b) to stimulate the development of informal entrepreneurship.

Entrepreneurship is the pursuit of an opportunity irrespective of the resources (Amine \& Staub 2009:183). An entrepreneur is defined as somebody who is actively involved in starting a business or 
is the owner of a business (Harding et al. 2005). The informal sector was historically defined as being in opposition to the formal sector, and Chen (2012) stated that it would disappear once developing countries achieved sufficient economic growth. There is a wide range of entrepreneurial activities included in the informal economy, such as street vendors, taxi drivers, rubbish collectors, food markets and home-based care workers, making it almost as diverse as the formal economy. Informal businesses are unregistered, unregulated and untaxed businesses that are often run from street pavements or homes or according to other informal arrangements (Horn 2011). Wilkinson (2013) notes that:

these units typically operate at a low level of organisation with little or no division between labour and capital factors or production and on a small scale. They have low bargaining power and fierce cost cutting competition render them unable to operate like formal sector entities. (p. 14)

The relative share of the informal economy by province indicates a correlation with the overall unemployment rate, supporting the idea that for many people the informal economy is the alternative to unemployment. It is argued that without the informal economy, the unemployment rate would rise from the current $25 \%$ to $47.5 \%$ (Stats SA 2014).

\section{Women-owned informal businesses}

The emergence of a growing community of women entrepreneurs has been described as the most significant economic and social development in the world. A key phenomenon in most rural villages in developing economies is the emergence of female heads of households. The economic landscape of South African rural villages displays similarities such as that the men migrate to urban areas to earn a living while the women stay behind to raise their children. In parts of Kenya and Tanzania, over $50 \%$ of households are headed by women because of the migration of men to urban industrial sectors. In most parts of the world, including developing nations, women are a powerful force in their communities. When women earn an income and control what they do with the money, their children are more likely to finish school, their families eat better and stay healthy, their communities thrive and entire nations are in a better economic position.

Literature from India and Sri Lanka (De Mel, McKenzie \& Woodruff 2013), Somalia (Ali \& Ali 2013), Ghana (Akpalu, Alnaa \& Aglobitse 2012), Nigeria (Otoo et al. 2012) and South Africa (Siqwana-Ndulo 2013) point to the fact that during the last two decades women are increasingly becoming the primary economic providers of their families going out to markets to do business.

There is a significant body of literature in social work on the importance of helping women to increase their influence over their lives and their environments. However, central to poor women exercising control over their lives should be the improvement of their economic condition (Raheim \& Bolden 1995). Women business owners cite a number of reasons for becoming entrepreneurs. An analysis of the main reasons includes an increase in income, attractions of entrepreneurship, self-determination and autonomy, family concerns such as balancing career and family and the lack of career advancement. It was found that semi-literate women in developing countries start more businesses than men because of social inequalities they face and their access to other job opportunities (Williams \& Gurtoo 2012).

The desire to make a social contribution seems to be a strong motivating factor for women entrepreneurs. Research suggests that this caring attitude manifests in women's leadership style and that goals other than economic growth guide women's businesses. There is a strong belief amongst women that a successful business should give back to the community, thus enforcing the social contribution factor (Williams \& Gurtoo 2012).

\section{Barriers women face to entering the informal business world}

Starting a business is difficult under the best circumstances and is made even more difficult in Sub-Saharan Africa by complex environmental factors (Amine \& Staub 2009). Factors that have been identified by various researchers as barriers to women-owned informal enterprises are discussed below.

\section{Access to finance}

Inadequate access to credit by the poor has been identified as one of the factors that contribute to poverty (Hobson 2011). Women informal entrepreneurs find it extremely difficult and often impossible to access credit through the formal credit system (Otoo et al. 2012). Formal lending institutions are averse to financing smaller loans because of the high administration and information costs and high risk with little collateral (Otoo et al. 2012). Women in rural communities are especially vulnerable to the regulatory discrimination of financial institutions (Amine \& Staub 2009).

O'Neill and Viljoen (2001) described the following specific problems faced by women entrepreneurs who tried to obtain finance: no credit record, most assets registered in husband's name, inability to qualify for loans because of stringent criteria applied by banks and a lack of business and management skills.

An increase in women's access to microfinance could potentially contribute to increasing efficiency in output and consequently reduce poverty and empower women (Akpalu et al. 2012). Informal women entrepreneurs do not need large amounts of money to get started. Amine and Staub (2009) found that microloans to women of less than $\$ 100$ have brought about profound growth in their enterprises.

\section{Support systems}

One of the crucial barriers to women succeeding in business is the lack of support systems around them. Women are socially defined as the caretakers of the family: they look 
after their children, care for their husbands and family units and are more likely to be socially punished for not fulfilling this role (DTI 2005). Women suffer from a lack of support from families. The community finds it difficult to accept the female entrepreneur and men are prejudiced towards the woman entrepreneur (O’Neill \& Viljoen 2001). Social support from family and friends who provide positive role models as well as from parents who promote entrepreneurial aspirations during childhood contributes to create positive environmental conditions favouring women's entrepreneurship (Amine \& Staub 2009).

\section{Poor access to information and advice}

Chiloane and Mayhew (2010) and Stander (2011) found that in South Africa there was a need to restructure local business service centres in the local communities in such a way that information could be more widely disseminated and accessed. Information on business networks should have been distributed in the same way as information about social services.

Hobson (2011) highlighted a lack of entrepreneurial spirit and knowledge in the field of business, a lack of acceptance in the community and male prejudices as well as a lack of management skills as barriers to entering informal business enterprises.

\section{Limited access to basic infrastructure and services}

Women's roles and responsibilities in Sub-Saharan Africa are made more difficult and time-consuming because of problems caused by a lack of basic infrastructure and services at the local level, such as clean water, electricity, reliable transportation and modern communication (Amine \& Staub 2009). A lack of transport, inadequate access to market stalls and toilet facilities and the high incidence of HIV- and/or AIDS-related illnesses further complicate their situation (Hobson 2011).

\section{Motivational orientations to enter entrepreneurship}

Women's entrepreneurial activities are increasingly promoted as a means of creating growth and development. They are not a homogenous group, and their motivations for entry as well as performance of their business vary significantly (Franck 2012).

Most rural women in the informal sector in South Africa had been raised in strict traditional homes, had little education, married relatively young and had little or no urban experience (Mitchell 2004). While generation of income, whether for profit or sustaining family livelihood, is a driving force behind women's informal entrepreneurship, there is also growing recognition that it is not only motivated by poverty. Informal enterprises may be motivated by a variety of 'voluntary' and 'opportunity'-driven factors (Franck 2012). The factors that motivate women to become entrepreneurs can also be described as 'necessity' or push factors or 'opportunity' or pull factors, or a combination of both (Ali \& Ali 2013).

Push factors are factors that encourage women to start business enterprises driven by financial need because of the family situation (Ali \& Ali 2013). Push factors are a product of desperate conditions; entrepreneurship is the only option available to earning a living, rather than a positive choice. According to Ali and Ali (2013) push factors are factors such as insufficient family income, dissatisfaction with a salaried job, difficulty in finding work and a need for flexible work schedules because of family conditions. Opportunity or pull factors are the factors associated with perceptions of entrepreneurship as an enticing avenue for a better, more fulfilling life and are associated with independence, fulfilment, entrepreneurial drive and desire for wealth, social status and power (Ali \& Ali 2013).

Women entrepreneurs tend to be motivated by the need to provide security for their families and their family circumstances and not profit maximisation (Mitchell 2004). Women are motivated by their need for independence, economically and otherwise. Furthermore, entrepreneurship allows women to combine caring for their family with bringing in the money needed for day-to-day survival.

\section{Development of women entrepreneurs}

Constraints common to all informal enterprises tend to be particularly severe for female informal enterprises. There are many factors that affect the development of women entrepreneurship in Sub-Saharan Africa (De Vita, Mari \& Poggesi 2014). The first problem identified by De Vita et al. (2014) is closely related to family responsibilities: high fertility rates of five to six births per woman. This has a considerable effect on personal consequences for women who try to start their own enterprises (Amine \& Staub 2009; De Vita et al. 2014).

The second problem, which is related to the first, is the low social recognition accorded to women entrepreneurs. SubSaharan Africa men believe that independent and successful women do not deserve to be considered chaste and worthy of respect (De Vita et al. 2014). Customary patriarchal norms and rules are still in place. Sub-Saharan women seem to be struggling to find acceptance in the market and respect from their customers (De Vita et al. 2014). This finding contradicts the results of O'Neill and Viljoen (2001) that South African women are now more accepted as equals, that government policies in South Africa favour women and that women are entering the market at a faster rate than before. Mazonde and Carmichael (2016) interviewed 43 female entrepreneurs in Zimbabwe and the majority of the participants reported that their husbands looked down on their entrepreneurial activities. In an effort to keep their family intact, these women were willing to bow to patriarchy.

The third problem identified by De Vita et al. (2014) is related to inadequate education and training of business women. 
The impact of education on performance is more pronounced in women-owned businesses. A lack of market information, managerial skills and technical competence limits the participation of women in value-adding business and the size of the enterprises that are often small and where most employees are unskilled (De Vita et al. 2014).

Education and training are key elements in successful enterprise creation (Omwenga, Mukulu \& Kanali 2013). The authors, in their study of women entrepreneurs in Nairobi, Kenya, found that many more women than men lack the requisite level of education and training, including business and technical skills and entrepreneurship training. They also found that women were often disadvantaged in terms of access to training. Women were often unaware of training opportunities and less likely to be able to afford the cost of training (Omwenga et al. 2013).

Many of the opportunity or pull factors resonate with concepts from the field of positive psychology (Wissing et al. 2015). A focus on 'what went right' as opposed to 'what went wrong' could provide a more optimistic description regarding the status of informal women entrepreneurship in the NorthWest Province in South Africa.

The 2015 Female Entrepreneurship Index (Terjesen \& Loyd 2015) analyses 77 countries, which is an increase from 30 in 2014. The index utilises an established theoretical framework to measure entrepreneurial environment ecosystems and individual aspirations and score nations from 0 to 100 . The 2015 index revealed that despite global progress, $61 \%$ of the nations (47 of 77) scored below 50 points - an indication that these countries must pursue significant changes in order to reduce barriers for female entrepreneurs. According to the study, South Africa ranked in the 36th place with a score of 44.5 of the 77 countries. From a Sub-Saharan perspective, South Africa ranked the highest and Malawi the lowest, where globally, Malawi scored second lowest overall in the 76th place with an index of 15.5., almost equal to Pakistan (77th place) in the last position with a score of 15.2. Table 1 presents the Sub-Saharan Female Entrepreneurship Index scores for African countries.

Scholars in the developing world have begun to acknowledge the significant role of the informal economy in employment provision and its function as a buffer between employment

\begin{tabular}{lll}
\multicolumn{2}{l}{ TABLE 1: Sub-Saharan Africa score. } \\
\hline Rank & Country & Score \\
\hline 36 & South Africa & 44.2 \\
53 & Botswana & 36.4 \\
57 & Nigeria & 32.8 \\
64 & Zambia & 29.1 \\
68 & Angola & 26.0 \\
69 & Ghana & 25.8 \\
72 & Ethiopia & 20.9 \\
74 & Uganda & 18.4 \\
76 & Malawi & 15.5 \\
\hline Source: Terjesen, S.A. \& Lloyd, A., 2015, The 2015 Female Entrepreneurship Index, Kelley
\end{tabular}
Source: Terjesen, S.A. \& Lloyd, A., 2015, The 2015 Female
School of Business Research Paper No. 15-51, Bloomington and unemployment. South Africa exhibits a broad range of maturity of LED activity. It seems that despite the growth in policy significance of LED, there is still a need to study and capture data on LED experiences in South Africa.

\section{Research methodology}

A quantitative research methodology was adopted to determine the motivational factors affecting the women entrepreneurs in the Mahikeng district. The population was described as all the informal women entrepreneurs in the Mahikeng district in North-West Province. These businesses are unrecorded and the exact population size could not be determined. Non-probability sampling was used in the absence of a formal list of informal women-owned businesses in the area. A snowball sampling technique had to be applied as the first woman entrepreneur referred the researcher to the next participant. The benefit of this technique includes the ability to obtain a large number of participants quickly and at a low cost (Leedy \& Ormrod 2015). In total, 80 respondents completed the survey through face-to-face interviews during a period of 2 weeks. A pilot study preceded a structured questionnaire that was personally administered face-to-face with the assistance of an interpreter. During the pilot phase, the researcher conducted five interviews with informal women entrepreneurs in the area to refine the questionnaire and identify any other relevant concepts that needed to be addressed in the survey. Following the pilot interviews, the questionnaire was finalised with five sections, namely a demographic section, a section to measure the characteristics of the businesses, a section to measure the perceived motivational factors to start a business, a section to measure the perceived inhibiting factors that prevent women entrepreneurship and a section to determine the development needs of the women entrepreneurs who participated in the study. This article will only report on the motivational factors of women to start an informal business, that is, the 15 questions contained in Section $C$ of the questionnaire.

The results of this study are not generalisable to the greater population of South Africa because of the sample size and are relevant for the Mahikeng region only.

\section{Ethical consideration}

Ethics approval was obtained from the School of Business Leadership, UNISA Ethics Committee and the participants' right to privacy and anonymity was respected. Participants were also informed that they could withdraw at any stage should they want to terminate the interviews.

\section{Demographic information}

The demographic information of the respondents is summarised in Table 2. In terms of age, the majority of the respondents $(65 \%)$ were older than 40 years. It is clear that the younger generation is not attracted to the informal sector because only $7.5 \%$ were younger than 29 years. Almost half of the respondents (45\%) were single and only $21 \%$ had 
TABLE 2: Demographics of the sample $(n=80)$.

\begin{tabular}{llc}
\hline Demographic variable & Category & $\mathbf{\%}$ \\
\hline Marital status & Single & 45.5 \\
& Married & 54.5 \\
Age & $>40$ years & 65.0 \\
& $<29$ years & 7.5 \\
Qualification & Matric & 21.0 \\
& Post-matric & 2.0 \\
Years in business & Less than 1 year & 8.0 \\
& 1-3 years & 16.0 \\
& More than 6 years & 60.0 \\
\hline
\end{tabular}

completed matric. Less than $2 \%$ of the respondents had a post-matric qualification or a degree.

This affirmed that the majority of informal woman entrepreneurs are not well educated and therefore not marketable to the formal sector. They have basic literacy and numeracy skills and need to enhance them to manage a profitable business. The majority of respondents (81\%) used personal savings to start their business. None of the respondents had access to any microloans or finance from banks. The majority of the respondents $(60 \%)$ had been in the informal business for more than 6 years. Only 8\% of respondents had been in business for less than a year and $16 \%$ of the women reported a period of $1-3$ years.

\section{Statistical analysis}

The data were captured manually during the face-to-face interviews, coded into MS Excel for data cleaning and editing and imported into SPSS version 22 for analysis.

According to Pallant (2011), principal component analysis (PCA) is the most common method of exploratory analysis. The aim of a PCA is to arrive at a relatively small number of factors and transform the original variables into smaller sets of linear combinations, with all of the variance in the variables being used (Pallant 2011). The research aimed to identify relevant underlying hypothetical constructs emerging from the data that could add to the interpretation of the data, describe the relationships between possible constructs and present motivational factors that affect women entrepreneurs to start their own informal businesses.

The first step in PCA is to assess the suitability of the data for a factor analysis, followed by a factor extraction and finally a factor rotation and interpretation (Pallant 2011). An exploratory analysis of the 15 items was performed on the data to determine which items could be reduced to underlying dimensions. PCA was concerned only with establishing which linear components existed within the data and how a particular variable might contribute to that component (Field 2009). The authors inspected the correlation matrix for evidence of coefficients greater 0.3 , indicating sufficient strength of intercorrelations amongst the items to continue with the analysis (Tabachnick \& Fidell 2013), which was indeed the case.

Consequently, a factor extraction was performed to determine the smallest number of factors or components that can be
TABLE 3: Kaiser-Meyer-Olkin measure of sampling adequacy and Bartlett's test of sphericity.

\begin{tabular}{lcccc}
\hline Measures of sampling adequacy & Score & $\begin{array}{c}\text { Approximate } \\
\text { chi-square }\end{array}$ & $d f$ & Sig. \\
\hline $\begin{array}{l}\text { Kaiser-Meyer-Olkin measure of } \\
\text { sampling adequacy }\end{array}$ & 0.58 & - & - & - \\
Bartlett's test of sphericity & - & 343.959 & 105 & $<0.001$ \\
\hline
\end{tabular}

$d f$, degrees of freedom; Sig, level of significance.

used to best represent the interrelationships amongst the components. Although the intercorrelations amongst the items indicated sufficient strength, they were not particularly high and the authors decided on an orthogonal rotation, and specifically a Varimax rotation. This rotation attempts to maximise the dispersion of loadings within factors (in this case motivational factors of women to start informal businesses). Furthermore, Varimax intends to load a smaller number of variables highly onto each factor resulting in more interpretable clusters of factors (Tabachnick \& Fidell 2013).

Two additional measures to help assess the factorability of the data were calculated. The Kaiser-Meyer-Olkin measure of sampling adequacy was calculated, and according to Pallant (2011) a value of 0.6 is adequate for a good factor analysis. A value of 0.58 was calculated, which the authors accepted as an adequate value to proceed with the analysis. The Bartlett's test of sphericity should be significant $(p<0.05)$ as Tabachnick and Fidell (2013) stated and was calculated at a significant measure of $p<0.001$.

Table 3 illustrates the validity and reliability of the constructs measured. Cronbach's alpha coefficients were calculated to determine the validity and reliability of the constructs measured in the questionnaire. Tabachnick and Fidell (2013) stated that a Cronbach's alpha score determines the internal consistency of a scale and is expressed as a value between 0 and 1 . Adequate measuring values of Cronbach's alpha range from 0.70 to 0.95 (Tabachnick \& Fidell 2013). In agreement, Pallant (2011) noted that alpha values of 0.70 and higher are considered suitable. However, in exploratory research within social sciences, a cut-off point may be reduced (Pallant 2011) and accordingly, the authors accepted 0.5 to describe the motivational factors for women entrepreneurs in Mahikeng to start their own businesses.

\section{Ethical consideration}

Ethical clearance was granted by UNISA SBL before the research commenced.

\section{Results and discussion}

The process of the identification of the underlying motivational factors is presented in this section. The descriptive statistics in Table 4 presents three components of which the outstanding component is C2. This deduction is made from the high weighted mean score (4.61) with the lowest being that of 'Passion for Product' (3.14). The Cronbach's alpha coefficients of the three components are acceptable if Pallant's guideline of a cut-off point of $>0.50$ for exploratory social research is applied. 
TABLE 4: Descriptive statistics and Cronbach's alpha coefficient.

\begin{tabular}{|c|c|c|c|c|c|c|}
\hline Component & $\mathbf{N}$ & Mean & Maximum & Minimum & Standard deviation & Cronbach's alpha \\
\hline $\mathrm{C} 1$ & 80 & 4.40 & 5.00 & 1.00 & 0.76 & 0.81 \\
\hline $\mathrm{C} 2$ & 80 & 4.61 & 5.00 & 1.50 & 0.83 & 0.69 \\
\hline C4 & 80 & 3.14 & 5.00 & 1.00 & 1.12 & 0.50 \\
\hline
\end{tabular}

$\mathrm{C} 1$, entrepreneurial spirit; $\mathrm{C}$, destitute conditions; $\mathrm{C} 4$, passion for product.

TABLE 5: Varimax-rotated component matrix: Motivation to start a business.

\begin{tabular}{|c|c|c|c|c|c|c|}
\hline \multirow[t]{2}{*}{ Items } & \multicolumn{6}{|c|}{ Components } \\
\hline & 1 & 2 & 3 & 4 & 5 & 6 \\
\hline C4: Self-fulfilment & 0.890 & 0.004 & 0.011 & 0.050 & -0.021 & 0.046 \\
\hline C1: The need for independence & 0.830 & 0.182 & -0.084 & -0.033 & 0.127 & -0.075 \\
\hline C3: Need for a challenge & 0.757 & -0.187 & -0.176 & 0.266 & -0.056 & 0.114 \\
\hline C11: Insufficient family income & 0.021 & 0.798 & 0.042 & 0.016 & 0.256 & 0.040 \\
\hline C8: Difficulty finding a job & 0.065 & 0.786 & -0.028 & 0.097 & 0.049 & 0.111 \\
\hline C7: Redundancy & -0.110 & 0.538 & -0.327 & 0.210 & -0.212 & -0.456 \\
\hline C10: Compatibility with family duties & -0.124 & 0.085 & 0.862 & -0.059 & 0.116 & 0.080 \\
\hline C2: Need for flexible working schedule & -0.036 & -0.116 & 0.825 & 0.111 & -0.222 & -0.065 \\
\hline C9: Dissatisfaction with salaried jobs & 0.008 & 0.429 & 0.170 & 0.724 & -0.049 & -0.166 \\
\hline C15: Confidence in the product or service offered & 0.410 & 0.063 & -0.433 & 0.619 & 0.058 & 0.191 \\
\hline C5: To develop my hobby & 0.148 & -0.524 & 0.053 & 0.614 & 0.143 & -0.123 \\
\hline C6: Role models and other peoples influences & 0.145 & 0.029 & 0.012 & -0.088 & 0.779 & -0.229 \\
\hline C13: Ensure high job security & .010 & 0.204 & 0.014 & 0.448 & 0.671 & 0.206 \\
\hline C14: Entered the family business & 0.043 & 0.140 & -0.031 & -0.025 & -0.149 & 0.874 \\
\hline
\end{tabular}

The factor matrix and its loadings account for the common factor variance but did not provide a scientific meaningful structure for easy interpretation as described. The Varimaxrotated matrix in Table 5 presents a simpler structure (in bold) that is easier to interpret.

The Cronbach's alpha values for these configurations were established and the items were re-grouped and re-defined as Component 1: 'Entrepreneurial Spirit', Component 2: 'Destitute conditions', and Component 4: 'Passion for Product'. Table 6 explains the items, the Cronbach's alpha values and the new component descriptions.

Entrepreneurial Spirit (Cronbach's alpha score $=0.81$ ) is described by the items Self-fulfilment; Need for independence and Need for a challenge. These items can be defined as pull factors as women aspire towards certain ambitions, which are intrinsically motivated.

Destitute conditions (Cronbach's alpha score $=0.69$ ) are associated with the items 'Insufficient family income' and 'Difficulty finding a job'. These items can be defined as push factors and extrinsically motivated as women aspire to escape and move away from their unfortunate circumstances such as poverty and dependence on their male partners.

Passion for Product (Cronbach's alpha score $=0.50$ ) is associated with the items 'Confidence in the product' and 'Develop my hobby' and is also perceived as a pull factor, that is behaviour that is intrinsically motivated.

Component 3: Ambition; Component 5: Traditional role and Component 6: Family history all had Cronbach's alpha scores
TABLE 6: Transformed components: Motivation to start a business.

\begin{tabular}{lll}
\hline Items & $\begin{array}{l}\text { Cronbach's } \\
\text { alpha }\end{array}$ & $\begin{array}{l}\text { Component } \\
\text { description }\end{array}$ \\
\hline $\begin{array}{l}\text { C4: Self-fulfilment } \\
\text { C1: Need for independence } \\
\text { C3: Need for a challenge }\end{array}$ & 0.81 & $\begin{array}{l}\text { Component 1: } \\
\text { Entrepreneurial spirit }\end{array}$ \\
$\begin{array}{l}\text { C11: Insufficient family income } \\
\text { C8: Difficulty finding a job }\end{array}$ & 0.69 & $\begin{array}{l}\text { Component 2: Destitute } \\
\text { conditions }\end{array}$ \\
$\begin{array}{l}\text { C6: Role models } \\
\text { C13: Ensure high job security }\end{array}$ & 0.27 & Component 3:Ambition \\
C12: Desire for wealth & 0.50 & $\begin{array}{l}\text { Component 4: Passion for } \\
\text { product }\end{array}$ \\
$\begin{array}{l}\text { C15: Confidence in the product } \\
\text { C5: Develop my hobby }\end{array}$ & & $\begin{array}{l}\text { Component 5: Traditional } \\
\text { role }\end{array}$ \\
C10: Compatibility with family duties \\
C2: Need for flexible working schedule & 0.46 & $\begin{array}{l}\text { Component 6: Family } \\
\text { history }\end{array}$ \\
C14: Entered the family business & No value &
\end{tabular}

below 0.50 and were therefore not included as motivational factors in the conclusions.

Following the identification of the underlying factors and confirmations of internal consistency reliability, the summated ratings of these factors were calculated with the aim of establishing the ranking of the three most prevalent motivational factors as well as information regarding training interventions and obstacles women entrepreneurs in informal businesses experience. A 5-point Likert scale was designed to measure the extent to which the respondents agreed or disagreed with the statement where $1=$ 'Agree to a very great extent', 2 = 'Agree to a great extent', 3 = 'Agree to some extent', $4=$ 'Agree to a limited extent' and $5=$ 'Agree to no extent' at all. The responses are reported as Top2Box scores (the sum of Agree to a very great extent and Agree to a great extent). 
Regarding the three key motivational factors as indicated by PCA, $83 \%$ of the respondents indicated 'Destitute conditions' as the key driver for starting an informal business, followed by $78 \%$ of women who indicated 'Entrepreneurial Spirit' as the second most important motivational factor. 'Passion for Product' was rated the third most important reason for starting a business by $43 \%$ of the respondents.

Although the South African government established many pro-women support structures over the last two decades to provide a variety of support to emerging entrepreneurs, the need for gender-specific and informal sector-specific training and development still exists. In terms of their training and development needs, $91 \%$ of the women interviewed indicated that they had never been exposed to any training programmes by government or a private organisation. Figure 1 depicts the fact that only $9 \%$ of the respondents agreed that they have been exposed to training.

Regarding the obstacles that the women experience, it was the lack of business and financial skills that was ranked as the biggest obstacle to a successful business with a score of $43.4 \%$. The second biggest obstacle is the lack of a business network (38.5\%), which is necessary in maintaining and expanding an informal enterprise, as is clear in Figure 2.

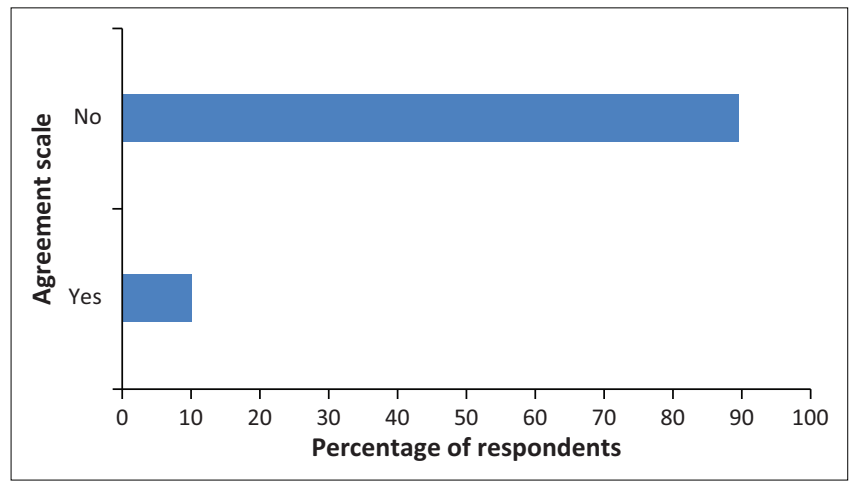

FIGURE 1: Have you ever been trained by government or private sector?
The results of this study indicate that women in the informal sector are less educated and have fewer marketable skills with most of the respondents not having a secondary qualification. One way to address this challenge is through skills training; however, access to training has also been identified as a barrier and must be addressed. The skills required are varying business skills, life skills and even literacy, numeracy and communication skills.

Informal women entrepreneurs are firstly driven by the need to survive as was shown by $83 \%$ of the respondents who agreed to a great extent and a very great extent that they do business to escape poverty. As an extrinsic motivation, it pushes them towards creating security for their family and not towards profit maximisation. They are driven to entrepreneurship out of necessity or destitution. Their entrepreneurial activities are viewed as a safety net that provides employment and income-earning opportunities for those excluded from formal sector employment. Many women engaged in the informal sector would in its absence be unemployed and unable to access alternate forms of income.

There was only a $5 \%$ difference between the ranking score of 'Destitute conditions' (a push factor scored at 83\%) and 'Entrepreneurial Spirit' (a pull factor scored at 78\%), the two key motivational factors that were identified in PCA.

The role of the woman in the home as the primary caregiver and often the breadwinner was ranked in the third position $(50 \%)$ as a motivating factor for women to enter informal business entrepreneurship. The responsibility of parenting resides with women. Many respondents were single mothers, receiving little or no support from their partners. Entering business because of a family history was the weakest driver and scored $30 \%$.

\section{Conclusion}

The public and the private sector need to recognise the importance of the informal business sector in South Africa.

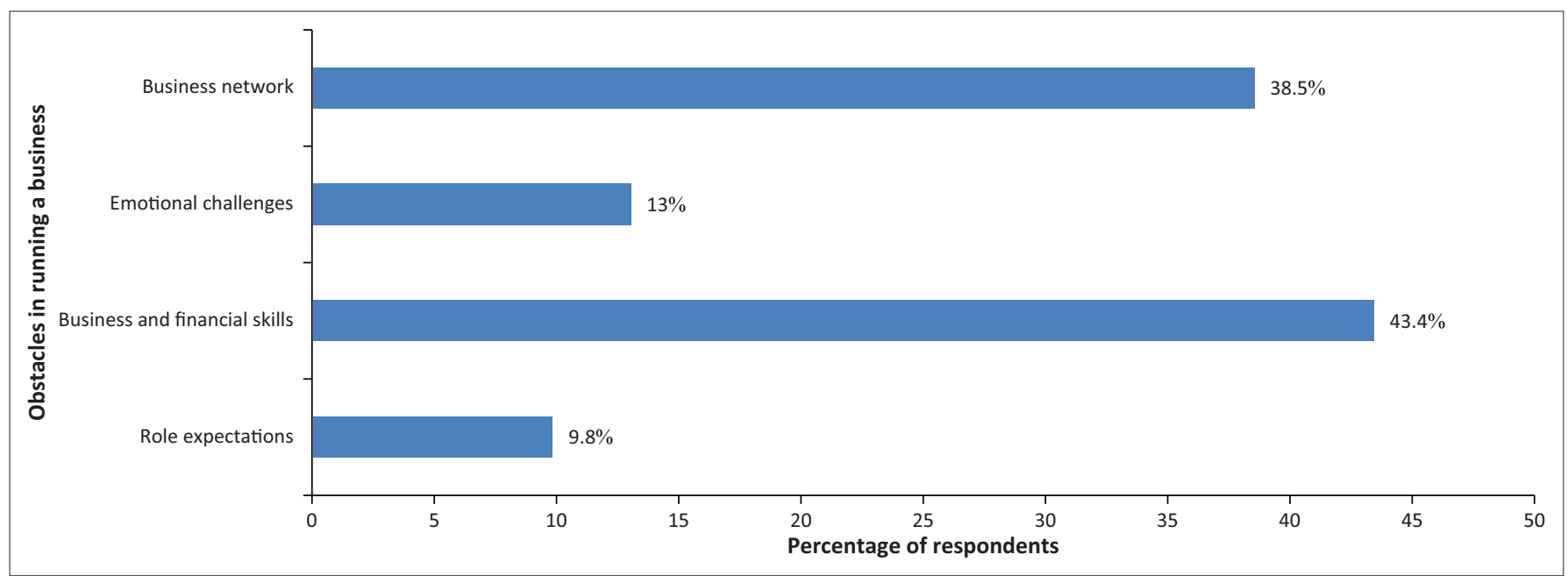

FIGURE 2: What are the main obstacles for running your business? 
With a labour force participation rate of 2.3\% (Stats SA 2014) the rural villages in the Mahikeng district in North-West do not paint a picture of growth and prosperity.

A key insight was gained as a result of the almost equal ratio of intrinsic to extrinsic motivation. The need to transcend impoverished conditions and the need for selfdetermination were almost equally strong amongst the 80 participants. In contrast to Hobson (2011) who identified a lack of entrepreneurial spirit as a barrier to growth, this is not the case amongst the women from the North-West. Although the primary motivating factor to start an informal business was 'Destitute conditions' (83\%), many respondents shared a passion for business and a high entrepreneurial flair $(78 \%)$.

Access to training may lead to business growth and stimulate the economic growth of the province. Initiatives could include the facilitation of microloans, managing and coaching of business skills as well as sponsorships for sustainable growth. The improvement of basic facilities and infrastructure such as water sanitation, transport, refuse removal and power and lighting through solar systems will support informal businesses. The establishment of a national database would assist the government in fully understanding the impact of this sector on GDP, unemployment and poverty alleviation. The database could be used by large organisations to collaborate with this sector to gain a competitive advantage.

An entrepreneurial spirit mixed with the right amount of skills training could enhance the performance of informal female entrepreneurs. If fully developed, it could lead these women entrepreneurs to move out of survival mode into profit maximisation.

While the most important obstacle to running a business was reported as the lack of financial and business skills, $91 \%$ of the participants reported that they had never received any training from government or the private sector. Competence is a necessary skill and an enabler of a self-efficacy, that is, the belief that you are the master of your own destiny. Building on strengths is more effective than trying to improve weaknesses (Biswas-Diener \& Dean 2007).

Self-efficacy behaviour without the necessary support will take informal women entrepreneurs only so far. The little train in The Little Engine That Could (Piper 1978) is motivated and believes in her ability to move up a steep hill to deliver the goods because she has enough wagons with strong wheels and sufficient coals to keep her moving forward on a well-built railway track. Access to basic infrastructure, training, funding and business networks will enable selfefficacy behaviour of women entrepreneurs in the Mahikeng district to move themselves and their communities around the mountains of poverty to prosperity, from I think I can to I did it.

\section{Acknowledgements Competing interests}

The authors declare that they have no financial or personal relationship(s) that may have inappropriately influenced them in writing this article.

\section{Authors' contributions}

S.H. wrote the complete article, included additional literature and did extra data analysis on the initial data. K.A. did the initial data collection and analysis as a MBL student

\section{References}

Akpalu, W., Alnaa, S.E. \& Aglobitse, P.B., 2012, 'Access to microfinance and intra household business decision making: Implication for efficiency of female owned enterprises in Ghana', The Journal of Socio-Economics 41(5), 513-518. https://doi. org/10.1016/j.socec.2012.04.020

Ali, A.H. \& Ali, A.Y.S., 2013, 'Motivational factors of Somali women entrepreneurs in the Benadir region', Academic Research International 4(1), 59.

Amine, L.S. \& Staub, K.M., 2009, 'Women entrepreneurs in sub-Saharan Africa: An institutional theory analysis from a social marketing point of view' Entrepreneurship and Regional Development 21(2), 183-211. https://doi. org/10.1080/08985620802182144

Ayub, M., 2013, 'Poverty and inequality', Global Journal of Emerging Market Economies 5(3), 329-346. https://doi.org/10.1177/0974910113505796

Bandura, A., 1982, 'Self-efficacy mechanism in human agency', American Psychologist 37(2), 122. https://doi.org/10.1037/0003-066X.37.2.122

Biswas-Dienr, R. \& Dean, B., 2007, Positive psychology coaching: Putting the science of happiness to work for your clients, Wiley, New York.

Bosma, N.S., 2014, 'The Global Entrepreneurship Monitor (GEM) and its impact on entrepreneurship research', Foundations and Trends in Entrepreneurship 9(2), 143-258. https://doi.org/10.1561/0300000033

Brown, K.W. \& Ryan, R.M., 2004, 'Fostering healthy self-regulation from within and without: A self-determination theory perspective', Positive Psychology in Practice, 7(1), 105-124.

Chen, M.A., 2012, The informal economy: Definitions, theories and policies, Women in Informal Economy Globalizing and Organizing: WIEGO Working Paper, 1.

Chiloane, G.E. \& Mayhew, W., 2010, 'Difficulties encountered by black women entrepreneurs in accessing training from the Small Enterprise Development Agency in South Africa', Gender and Behaviour 8(1), 2590-2602. https://doi. org/10.4314/gab.v8i1.54676

De Mel, S., McKenzie, D. \& Woodruff, C., 2013, 'The demand for, and consequences of formalization among informal firms in Sri Lanka', American Economic Journal: Applied Economics 5(2), 122-150. https://doi.org/10.1257/app.5.2.122

De Vita, L., Mari, M. \& Poggesi, S., 2014, 'Women entrepreneurs in and from developing countries: Evidences from the literature', European Management Journal 32(3), 451-460. https://doi.org/10.1016/j.emj.2013.07.009

DTI, 2005, South African Women Entrepreneurs: A burgeoning force in our economy, A special report, Department of Trade and Industry, Pretoria.

Field, A., 2009, Discovering statistics using SPSS, 3rd edn., Sage, London

Franck, A.K., 2012, 'Factors motivating women's informal micro-entrepreneurship: Experiences from Penang, Malaysia', International Journal of Gender and Entrepreneurship 4(1), 65-78. https://doi.org/10.1108/17566261211202981

Harding, R., Brooksbank, D., Hart, M., Jones-Evans, D., Levie, J., O'Reilly, J.O. et al., 2005, Global entrepreneurship Monitor, London Business School, London.

Hechavarria, D.M. \& Ingram, A.E., 2016, 'The entrepreneurial gender divide: Hegemonic masculinity, emphasized femininity and organizational forms', International Journal of Gender and Entrepreneurship 8(3), 242-281. https://doi. org/10.1108/IJGE-09-2014-0029

Hobson, E.W., 2011, 'The importance of the informal economy for local economic development (LED) in Africa', Local Economic Development Network of Africa 3(27), 1-8.

Horn, A., 2011, 'Who's out there? A profile of informal traders in four South African city central business districts', Town and Regional Planning 59, 1-6.

Leedy, P.D. \& Ormrod, J.E., 2015, Practical research planning and design, Pearson Educational International, New York.

Mazonde, N.B \& \& Carmichael, T., 2016, 'The influence of culture on female entrepreneurs in Zimbabwe', The Southern African Journal of Entrepreneurship and Small Business Management 8(1), 10. https://doi.org/10.4102/sajesbm. v8i1.101

Mitchell, B.C., 2004, 'Motives of entrepreneurs: A case study of South Africa', Journal of Entrepreneurship 13(2), 167-183. https://doi.org/10.1177/097135570401 300203 
Omwenga, J.Q., Mukulu, E. \& Kanali, C., 2013, 'Towards improving the performance of women entrepreneurs in small and medium enterprises in Nairobi County, Kenya: Policy recommendations', International Journal of Business and Social Science 4(9), 1-11.

O'Neill, R. \& Viljoen, L., 2001, 'Support for female entrepreneurs in South Africa: Improvement or decline?', Journal of Family Ecology and Consumer Science 29(1), $37-44$.

Otoo, M., Ibro, G., Fulton, J. \& Lowenberg-Deboer, J., 2012, 'Micro-entrepreneurship in Niger: Factors affecting the success of woman street vendors', Journal of African Business 13(1), 16-28. https://doi.org/10.1080/15228916.2012.657937

Pallant, J., 2011, SPSS survival manual: A step by step guide to data analysis using SPSS, 4th edn., Allen and Unwin, Berkshire.

Piper, W., 1978, The little engine that could, Grosset and Dunlap, New York.

Prahalad, C., 2005, The fortune at the bottom of the pyramid: Eradicating poverty through profits, Pearson, New York.

Raheim, S. \& Bolden, J., 1995, 'Economic empowerment of low income women through self-employment programs', Affilia 10(2), 138-154. https://doi.org/ $10.1177 / 088610999501000204$

Saadaoui, S. \& Affess, H., 2015, 'Evaluating the role of coaching on developing entrepreneurial self-efficacy', European Journal of Business and Social Sciences 3(11), 54-61.

Sethuraman, S. \& Charmes, J., 1998, Linkages between gender, poverty and informa sector, University of Versailles, France: Institute of Development Research, World sector, Univers
Bank, Paris.

Siqwana-Ndulo, N., 2013a, The informal sector in South Africa: Women street traders in Durban Part 1. Durban. Viewed 14 August 2014, from http://www.polity.org.za/ article/the-informal-sector-in-south-africa-women-street-traders-in-durban-part-1
Siqwana-Ndulo, N., 2013b, The informal sector in South Africa: Woman street traders in Durban, Durban. Viewed 14 August 2014, from http://www.polity.org.za/
article/the-informal-sector-in-south-africa-women-street-traders-in-durbanpart-2

Snyder, C.R. \& Lopez, S.J., 2007, Handbook of positive psychology, Oxford University Press, New York.

South African LED Network, 2010, viewed 14 August 2014, from http://led.co.za/ topic/informal-economy

Stander, C.J., 2011, 'Exploring women entrepreneurship in selected areas in South Africa', Doctoral dissertation, North-West University.

Stats SA, 2014, Census 2013. Census in brief, Statistics South Africa, Pretoria, viewed 20 May 2016, from http://www.statssa.gov.za/publications/P0211/P02111st Quarter2012.pdf

Tabachnick, B.G. \& Fidell, L.S., 2013, Using multivariate statistics, 6th edn., Pearson Education, Boston, MA.

Terjesen, S.A. \& Lloyd, A., 2015, The 2015 Female Entrepreneurship Index, Kelley School of Business Research Paper No. 15-51, Bloomington.

Wilkinson, F. ., 2013. The dynamics of labour market segmentation. London:Elsevier.

Williams, C.C. \& Gurtoo, A., 2012, 'Evaluating competing theories of street entrepreneurship: Some lessons from a study of street vendors in Bangalore, India', International Entrepreneurship and Management Journal 8(4), 391-409. https://doi.org/10.1007/s11365-012-0227-2

Williamson, M., 2005. Our deepest fear. A Return to Love: Reflections on the Principles of a Course in Miracles, Hay House, New York.

Wissing, M., Potgieter, J., Nel, L., Guse, T. \& Khumalo, T.F., 2015, Towards flourishing Contextualising positive psychology, Van Schaik Publishers, Pretoria. 